\title{
ALUMINIUM AND ACIDITY IN FINNISH SOILS
}

\author{
Armi Kaila \\ University of Helsinki, Department of Agricultural Chemistry
}

Received June 1, 1970

\begin{abstract}
In the present study an attempt was made to study by statistical methods the proportion of $\mathrm{Al}$ of the exchange acidity of 298 soil samples of various kind, and to what extent the titratable nonexchangeable acidity in these soils is connected with $\mathrm{Al}$, when $\mathrm{Al}$ soluble in Tamm's acid oxalate was used as its indicator.

Unbuffered $\mathrm{N} \mathrm{KCl}$ replaced $\mathrm{Al}$ only from soil samples with a $\mathrm{pH}$ less than 5.3 in 0.01 $\mathrm{M} \mathrm{CaCl}_{2}$. In this part of the material, $\mathrm{Al}$ corresponded, on the average, to one third of the exchange acidity of mineral soil samples, and to 16 per cent of that of organic soils. The amount of $\mathrm{Al}$ was usually the higher the lower the soil $\mathrm{pH}$, but the correlation was close only in the group of clay soils.

Titratable nonexchangeable acidity was estimated as the difference of the amount of acidity neutralized at $\mathrm{pH} 8.2$ and the corresponding amount of exchange acidity replaced by unbuffered $\mathrm{KCl}$. In 100 clay soil samples it was, on the average, $12.0 \pm 1.3 \mathrm{me} / 100 \mathrm{~g}$, in 42 samples of silt and loam soils $8.8 \pm 1.8 \mathrm{me} / 100 \mathrm{~g}$, in 99 sandy soils $8.9 \pm 1.1 \mathrm{me} /$ $100 \mathrm{~g}$ and in 57 organic soils $49.1 \pm 6.8 \mathrm{me} / 100 \mathrm{~g}$.

There was no correlation between titratable nonexchangeable acidity and the clay content within various soil groups. In the clay soils exalate soluble $\mathrm{Al}$ alone explained $78.3 \%$, in the silt and loam soils $59.8 \%$, in the sandy soils $6.5 \%$, and in the organic soils $0.6 \%$ of the variation in titratable nonexchangeable acidity. Taking into account the content of organic $\mathrm{C}$ increased the rate of explanation only to $82.1 \%$ in clay soils, to $84.1 \%$ in silt and loam soils, to $83,1 \%$ in sandy soils, and to $63.7 \%$ in the organic soils. Further, adding the soil $\mathrm{pH}$ increased the rate of explanation 5.8 to 9.6 per cent units in various soil groups, but considering of oxalate soluble Fe did no more distinctly increase the part of variation explained, except in the organic soils. Regression equations were calculated for the relationship of these variables.

According to the partial correlation coefficients and to the $\beta$-coefficients, the relative importance of oxalate soluble $\mathrm{Al}$ in explaining the variation in titratable nonexchangeable acidity was in the clay soils higher than even that of organic $\mathrm{C}$ content, but in the other mineral soil groups it was less important than both $\mathrm{C}$ content and $\mathrm{pH}$; in the organic soils even oxalate soluble $\mathrm{Fe}$ appeared to be slightly more important.
\end{abstract}

Modern concepts of soil acidity emphasize the role of aluminium. The exchange acidity replaced on leaching with unbuffered solution of a neutral salt is claimed to be mainly due to monomeric trivalent aluminium ions (Coleman et al. 1959, Jackson 1963, Chernov 1964), at least in soils low in organic matter (Schwertmann 1961). According to recent opinions, aluminium is connected also with titratable but nonexchangeable part or the total acidity which is neutralized first at a higher $\mathrm{pH}$. This " $\mathrm{pH}$-dependent acidity" which is 
usually supposed to be chiefly caused by weak acidic groups of organic matter, may be partly attributed to positively charged hydroxy-Al polymers. These complexes may be sorbed as surface coatings on soil particles, or they may block interlayer spaces of 2:1 clay minerals (Rich and Obenshain 1955, Barshad 1960, Clark 1964a, 1964b, Coleman et al. 1964, Schwertmann and Jackson 1964, de Villiers and Jackson 1967). Also part of the exchange sites of organic matter may be countered by fixed Al- or Al-hydroxy ions (Keränen 1946, Schnitzer and Skinner 1963, Clark 1964b, Schnitzer 1965, Pionke and Corey 1967, McLean and OWen 1969). These forms of aluminium are not exchangeable with a neutral salt, but they are proton donors or $\mathrm{OH}^{-}$acceptors, which will increase the consumption of base when acid soils are titrated. Hydroxy-Fe polymers are supposed to react in a similar way.

In the present work an attempt is made to study with statistical methods to what extent titratable nonexchangeable acidity in various kind of Finnish soils is connected with aluminium, when aluminium extracted by acid ammonium oxalate is used as its indicator. Attention is also paid to oxalate soluble iron, and to the contents of clay and organic carbon of the soils. The titratable nonexchangeable acidity is taken to correspond to the amount of acidity neutralized at $\mathrm{pH} 8.2$ minus the exchange acidity which is replaced by unbuffered KCl. Preliminary studies on aluminium in exchange acidity are also reported.

\section{Material and methods}

The material consists of 298 samples of various kind of soils, collected from different parts of Finland. In order to get very acid soils, also virgin samples were included. Both surface layers and deeper horizons were sampled.

According to the particle size composition, 100 of the samples were clay soils containing at least $30 \%$ of the fraction less than $2 \mu$ in diameter. There were 42 samples of silt and loam soils, 99 samples of sandy soils, or fine sand, sand and till soils, and 57 samples of organic soils which represented both peat soils and mull and mor layers.

The samples were air-dried and ground to pass the $2 \mathrm{~mm}$ sieve. Thus, particularly till soil samples lost a large part of their coarser components, and therefore, differ from the original soils.

The base consumed on leaching the soil samples with $\mathrm{N} \mathrm{KCl-triethanolamine,} \mathrm{buffered}$ to $\mathrm{pH} 8.2$, was taken as an estimate of the titratable acidity. The exchange acidity was displaced by unbuffered $\mathrm{N} \mathrm{KCl}$. In both cases, a $10 \mathrm{~g}$ sample of mineral soil, or a $2 \mathrm{~g}$ sample of organic soil was shaken for one hour in $20 \mathrm{ml}$ of the extracting solution and centrifuged. The soil was then washed with four $20 \mathrm{ml}$-portions of the extractant, and an aliquot of the combined extract was titrated.

$\mathrm{Al}$ in the unbuffered $\mathrm{KCl}$ extract was determined by the fluoride method (YUAN 1959), and the sum of exchanged $\mathrm{Ca}$ and $\mathrm{Mg}$ was estimated with versenate titration.

$\mathrm{Al}$ and Fe were extracted with Tamm's acid ammonium oxalate. The ratio of soil to solution was 1 to 20 , and the period of extraction was two hours. Al was determined by the aluminon method, and Fe by the sulfosalicylic procedure, after organic matter in the oxalate extract was destructed by ignition.

Organic $\mathrm{C}$ was determined by wet combustion and iodometric titration. Soil $\mathrm{pH}$ was measured in 1 to 2.5 suspension in $0.01 \mathrm{M} \mathrm{CaCl}_{2}$. 


\section{Results}

The groups of soil samples are characterized by data in Table 1 . The $\mathrm{pH}$ values range from 3.3 to 7.5 , but there are only a couple of samples with a $\mathrm{pH}$ higher than 6.7 . The very acid clay samples were from uncultivated postglacial soils rich in acid salts. The low mean $\mathrm{pH}$-value of the group of sandy soils is due to the fact that it contains more samples of virgin soil than the other groups of mineral soils. Typically, the mean $\mathrm{pH}$ of the organic soils is even lower.

Table 1. Soil samples

\begin{tabular}{|c|c|c|c|c|c|}
\hline \multicolumn{2}{|l|}{ Number of samples } & $\begin{array}{c}\text { Clay soils } \\
100\end{array}$ & $\begin{array}{c}\text { Silt and loam soils } \\
42\end{array}$ & $\begin{array}{l}\text { Sandy soils } \\
\quad 99\end{array}$ & $\begin{array}{c}\text { Organic soils } \\
57\end{array}$ \\
\hline $\mathrm{pH}\left(\mathrm{CaCl}_{2}\right)$ & mean & $5.2 \pm 0.2$ & $5.5 \pm 0.2$ & $4.9 \pm 0.1$ & $4.4 \pm 0.1$ \\
\hline & range & $3.3-7.5$ & $4.2-6.6$ & $3.4-6.5$ & $3.4-5.8$ \\
\hline \multirow[t]{2}{*}{ Org. C \% } & mean & $2.37 \pm 0.38$ & $2.21 \pm 0.57$ & $2.41 \pm 0.41$ & $25.50 \pm 3.37$ \\
\hline & range & $0.20-6.60$ & $0.10-6.40$ & $0.20-8.00$ & $8.60-48.3$ \\
\hline Oxalate soluble & mean & $12.4 \pm 1.1$ & $9.3 \pm 2.1$ & $12.0 \pm 1.7$ & $15.8 \pm 2.8$ \\
\hline $\mathrm{Al} \mathrm{mmol} / 100 \mathrm{~g}$ & range & $3.1-30.5$ & $2.0-34.6$ & $1.4-47.9$ & $0.6-46.8$ \\
\hline Oxalate soluble & mean & $13.2 \pm 0.7$ & $7.7 \pm 1.2$ & $5.5 \pm 0.7$ & $12.2 \pm 0.2$ \\
\hline $\mathrm{Fe} \mathrm{mmol} / 100 \mathrm{~g}$ & range & $1.7-39.4$ & $2.2-19.1$ & $0.5-19.4$ & $1.3-43.8$ \\
\hline Exchange acidity & mean & $1.5 \pm 0.4$ & $1.0 \pm 0.3$ & $1.1 \pm 0.2$ & $4.1 \pm 0.1$ \\
\hline $\mathrm{me} / 100 \mathrm{~g}$ & range & $0.1-9.9$ & $0.1-3.1$ & $0.2-6.8$ & $0.4-19.0$ \\
\hline \multirow{2}{*}{\multicolumn{2}{|c|}{$\begin{array}{l}\text { Titratable nonexchange-mean } \\
\text { able acidity me } / 100 \mathrm{~g} \text { range }\end{array}$}} & $12.0 \pm 1.3$ & $8.8 \pm 1.8$ & $8.9 \pm 1.1$ & $49.1 \pm 6.8$ \\
\hline & & $0.6-26.8$ & $0.9-20.5$ & $0.3-22.9$ & $17.4-106.5$ \\
\hline
\end{tabular}

Mean values with the confidence limits at the 95 per cent level

The three groups of mineral soils do not markedly differ in their contents of organic $\mathrm{C}$ or oxalate soluble Al. The content of oxalate soluble Fe tends to be somewhat higher in the clay soils and organic soils than in the groups of the coarser mineral soils.

On an average, exchange acidity is highest in the organic soils. This may be partly due to the lower ratio of extraction in these soils as compared with that in the mineral soils. In the mineral soils, the acidity replaced by unbuffered $\mathrm{KCl}$ is less than $10 \mathrm{me} / 100 \mathrm{~g}$, even in samples with a $\mathrm{pH}$ value below 3.5.

The proportion of $\mathrm{Al}$ in exchange acidity of these soils was studied only superficially. With the method used no $\mathrm{Al}$ was found in the $\mathrm{KCl}$ extract of soils with a $\mathrm{pH}$ higher than 5.3. There were two clay soils with $\mathrm{pH} 5.3$ which contained almost $0.1 \mathrm{me} \mathrm{Al} / 100 \mathrm{~g}$. About two thirds of the clay samples, and silt and loam samples were more acid than $\mathrm{pH}$ 5.3. To this part belonged $85 \%$ of the sandy soils, and $95 \%$ of the organic soils. Data for these samples are recorded in Table 2 .

One half of these organic soil samples did not contain $\mathrm{KCl}$-extractable Al. This was true also with one fourth of the clay soils and silt and loam soils, but only with one fifth of 
the sandy soils, with a $\mathrm{pH}$ value less than 5.3. The highest amounts of exchangeable $\mathrm{Al}$ were found in some very acid postglacial clay soils and in some virgin peat soils.

Table 2. Exchangeable $\mathrm{Al}$ in samples of $\mathrm{pH}$ less than 5.3

\begin{tabular}{|c|c|c|c|c|c|}
\hline & & \multirow{3}{*}{$\mathrm{pH}$} & \multicolumn{3}{|c|}{$\mathrm{Al}$ extracted by $\mathrm{N} \mathrm{KCl}$} \\
\hline & & & \multirow[t]{2}{*}{$\mathrm{me} / 100 \mathrm{~g}$} & \multicolumn{2}{|c|}{$\%$ of } \\
\hline & & & & $\mathrm{Al}+\mathrm{H}$ & CEC \\
\hline \multirow[t]{2}{*}{66 clay soils } & mean & $4.8 \pm 0.1$ & $1.2 \pm 0.5$ & $29 \pm 7$ & $11 \pm 5$ \\
\hline & range & $3.3-5.3$ & $0-8.7$ & $0-94$ & $0-74$ \\
\hline \multirow[t]{2}{*}{28 silt and loam soils } & mean & $4.7 \pm 0.1$ & $0.6 \pm 0.2$ & $33 \pm 10$ & $11 \pm 4$ \\
\hline & range & $4.2-5.2$ & $0-1.9$ & $0-69$ & $0-34$ \\
\hline \multirow[t]{2}{*}{84 sandy soils } & mean & $4.7 \pm 0.1$ & $0.6 \pm 0.2$ & $34 \pm 6$ & $16 \pm 4$ \\
\hline & range & $3.4-4.8$ & $0-5.1$ & $0-82$ & $0-75$ \\
\hline \multirow[t]{2}{*}{55 organic soils } & mean & $4.4 \pm 0.1$ & $1.0 \pm 0.5$ & $16 \pm 5$ & $5 \pm 2$ \\
\hline & range & $3.4-5.0$ & $0-7.3$ & $0-60$ & $0-30$ \\
\hline
\end{tabular}

Though the average content of exchangeable $\mathrm{Al}$ is equal in the clay soils and in the organic soils, the proportion of $\mathrm{Al}$ of the exchange acidity $(\mathrm{Al}+\mathrm{H})$, or of the cation exchange capacity $(\mathrm{Al}+\mathrm{H}+\mathrm{Ca}+\mathrm{Mg}$ in the $\mathrm{KCl}$ extract) is, on the average, distinctly lower in the organic soils than in the clay soils. Also in the other mineral soils, exchangeable $\mathrm{Al}$ corresponds to an, averagely, distinctly higher part of the exchange acidity than in the organic soils.

Other factors being equal, usually the amount of exchangeable $\mathrm{Al}$ tends to be the higher the lower the soil $\mathrm{pH}$ is. The regression is curvilinear, though often the part below $\mathrm{pH} 5$ in water or $\mathrm{pH} 4$ in $\mathrm{N} \mathrm{KCl}$ does not markedly deviate from a linear relationship. In the samples listed in Table 2, the amount of exchangeable $\mathrm{Al}$ as me/100 $\mathrm{g}$ is in the clay samples closely correlated with the soil $\mathrm{pH}$ (total linear correlation coefficient $\mathrm{r}=-0.91 * * *)$, far less closely in silt and loam soils $\left(\mathrm{r}=-0.66^{* * *}\right)$ and sandy soils $\left(\mathrm{r}=-0.58^{* * *}\right)$ and even more poorly in the organic soils $\left(\mathrm{r}=-0.48^{* * *}\right)$. The correlation between the proportion of $\mathrm{Al}$ of the exchange acidity and $\mathrm{pH}$ was marked only in the clay soils $\left(\mathrm{r}=-0.80^{* * *}\right)$. Elimination of the effect of organic $\mathrm{C}$ did not increase the correlation between $\mathrm{pH}$ and the proportion of $\mathrm{Al}$ in exchange acidity.

Titratable acidity neutralized at $\mathrm{pH} 8.2$ was very high in the peat samples, usually between 60 and $120 \mathrm{me} / 100 \mathrm{~g}$. In the other organic soils it was lower, but in every case markedly higher than the corresponding exchange acidity. Thus, even their difference, titratable nonexchangeable acidity, is high in the organic soils (Table 1). In the mineral soils this part of soil acidity ranges from 0.3 to $27 \mathrm{me} / 100 \mathrm{~g}$. There is no significant difference between the mineral soil groups in this respect, though the mean value of clay soils tends to be somewhat higher than the means of the coarser mineral soils.

The relation of titratable nonexchangeable acidity to other soil properties was first studied by calculating total and partial linear correlation coefficients between these variables. As could be expected, no correlation was found between titratable nonexchangeable acidity and the clay content within the various groups. The other results are recorded in Table 2. 
In the clay soils titratable nonexchangeable acidity is surprisingly closely correlated with oxalate soluble $\mathrm{Al}(\mathrm{r}=0.89 * * *)$, and even in the silt and loam samples this relation is distinct $\left(\mathrm{r}=0.77^{* * *}\right)$. In the sandy soils it is almost insignificant $\left(\mathrm{r}=0.25^{*}\right)$, and in the organic soils there is no correlation. Elimination of the effects of organic $\mathrm{C}, \mathrm{pH}$, and oxalate soluble $\mathrm{Fe}$ tends to decrease this correlation in clay soils and silt and loam soils, but to increase it in the other soil groups.

Though titratable nonexchangeable acidity is relatively closely correlated with the organic $\mathrm{C}$ content in all soil groups, taking into account the variation in oxalate soluble $\mathrm{Al}$ results in the clay soils in a low partial correlation coefficient, $\mathrm{r}=0.42 * * *$. In the silt and loam soils only a slight decrease is found, but in the sandy soils and organic soils no effect is detectable.

Elimination of the effect of oxalate soluble $\mathrm{Al}$ also decreases the closeness of correlation between titratable acidity and $\mathrm{pH}$ in the clay soils, but increases it in the sandy soils. Both in the clay soils and in the silt and loam soils, elimination of the effect of oxalate soluble $\mathrm{Al}$ reduces the correlation between titratable nonexchangeable acidity and oxalate soluble $\mathrm{Fe}$ to zero.

Partial correlation coefficients between titratable nonexchangeable acidity and each of the variables studied indicate that after the elimination of the effect of the three other variables, in clay soils the relation is relatively closest with oxalate soluble $\mathrm{Al}$. In the silt and loam soils the content of $\mathrm{C}$ and $\mathrm{pH}$ appear to be more important. This is more distinctly the case with the sandy soils, and in the organic soils even oxalate soluble Fe seems to deserve more attention than $\mathrm{Al}$ in this respect.

Calculation of the coefficients of determination and multiple determination shows that in the different soil groups the following percentage of variation in titratable nonexchangeable acidity may be explained by oxalate soluble $\mathrm{Al}$ and the other variables:

$\begin{array}{lcccc}\text { Explained by } & \text { Clay soils } & \begin{array}{c}\text { Silt and } \\ \text { loam soils }\end{array} & \text { Sandy soils } & \begin{array}{c}\text { Organic } \\ \text { soils }\end{array} \\ \text { Al } & 78.3 \% & 59.8 \% & 6.5 \% & 0.6 \% \\ \text { Al and C } & 82.1 \% & 84.1 \% & 83.1 \% & 63.7 \% \\ \text { Al, C, and pH } & 88.0 \% & 93.7 \% & 89.7 \% & 69.5 \% \\ \text { Al, C, pH and Fe } & 88.4 \% & 94.5 \% & 90.2 \% & 73.0 \%\end{array}$

On the other hand, variation in the C content alone will explain $59.9 \%$ of the variation in titratable nonexchangeable acidity in clay soils, $74.6 \%$ in loam and silt soils, $78.0 \%$ in sandy soils, and $60.5 \%$ in organic soils. Adding oxalate soluble $\mathrm{Al}$ increases the rate of explanation in the clay soils 22.2 per cent units, or by $55 \%$ of the variance left unexplained by organic C. In the silt and loam soils the corresponding values are 9.5 per cent units or $37 \%$, in the sandy soils 5.1 per cent units or $23 \%$, and in the organic soils only 3.2 per cent units or $8 \%$ of the variance left unexplained. These results also prove that there are marked differences between the various soil groups in the role of $\mathrm{Al}$ in titratable nonexchangeable acidity.

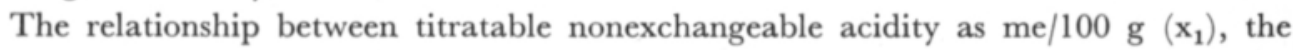
content of oxalate soluble $\mathrm{Al} \mathrm{mmol} / 100 \mathrm{~g}\left(\mathrm{x}_{2}\right)$, organic $\mathrm{C} \%\left(\mathrm{x}_{3}\right), \mathrm{pH}\left(\mathrm{x}_{4}\right)$, and oxalate soluble $\mathrm{Fe} \mathrm{mmol} / 100 \mathrm{~g}\left(\mathrm{x}_{5}\right)$ conforms to the following regression equations: 
In the clay soils

$$
\mathrm{x}_{1}=0.78 \mathrm{x}_{2}+0.87 \mathrm{x}_{3}-2.65 \mathrm{x}_{4}-0.12 \mathrm{x}_{5}+15.56
$$

The coefficient of multiple correlation is $\mathrm{R}=0.94 * * *$, and the standard error of estimate is $\mathrm{S}=2.45$.

In the silt and loam soils

$$
\begin{aligned}
& \mathrm{x}_{1}=0.19 \mathrm{x}_{2}+1.80 \mathrm{x}_{3}-2.60 \mathrm{x}_{4}+0.19 \mathrm{x}_{5}+14.06 \\
& \mathrm{R}=0.97 * * \text { and } \mathrm{S}=1.90
\end{aligned}
$$

In the sandy soils

$$
\begin{aligned}
& \mathrm{x}_{1}=0.19 \mathrm{x}_{2}+2.27 \mathrm{x}_{3}-3.03 \mathrm{x}_{4}+0.20 \mathrm{x}_{5}+14.65 \\
& \mathrm{R}=0.95^{* * *} \text { and } \mathrm{S}=1.62
\end{aligned}
$$

In the organic soils

$$
\begin{aligned}
& x_{1}=0.29 x_{2}+1.07 x_{3}-14.73 x_{4}+0.62 x_{5}+74.45 \\
& R=0.85^{* * *} \text { and } S=15.17
\end{aligned}
$$

The relative importance of these four factors affecting titratable nonexchangeable acidity may be compared on the basis of the following values of standard partial regression

\begin{tabular}{|c|c|c|c|c|}
\hline & Clay soils & Silt and loam soils & Sandy soils & Organic soils \\
\hline $\mathrm{r}_{12}$ & $0.89 * * *$ & $0.77 * * *$ & $0.25^{*}$ & -0.08 \\
\hline$r_{12,3}$ & $0.78 * * *$ & $0.61 * * *$ & $0.48 * * *$ & 0.25 \\
\hline$r_{12,34}$ & $0.72 * * *$ & $0.67 * * *$ & $0.64 * * *$ & $0.29 *$ \\
\hline $\mathrm{r}_{12,345}$ & $0.65 * * *$ & $0.54 * * *$ & $0.38 * * *$ & 0.21 \\
\hline$r_{13}$ & $0.74 * * *$ & $0.86 * * *$ & $0.88 * * *$ & $0.78 * * *$ \\
\hline$r_{13,2}$ & $0.42 * * *$ & $0.78 * * *$ & $0.90 * * *$ & $0.79 * * *$ \\
\hline$r_{13,24}$ & $0.51 * * *$ & $0.91 * * *$ & $0.94 * * *$ & $0.88 * * *$ \\
\hline$r_{13,2 \in s}$ & $0.46 * * *$ & $0.88 * * *$ & $0.92 * * *$ & $0.61 * * *$ \\
\hline$r_{14}$ & $-0.66 * * *$ & $-0.54 * * *$ & $-0.29 * *$ & $-0.59 * * *$ \\
\hline$r_{14,2}$ & $-0.50^{* * *}$ & $-0.50 * * *$ & $-0.46 * * *$ & $-0.58 * * *$ \\
\hline$r_{16,23}$ & $-0.57^{* * *}$ & $-0.78 * * *$ & $-0.62 * * *$ & $-0.41^{* *}$ \\
\hline$r_{16,23 s}$ & $-0.58 * * *$ & $-0.78 * * *$ & $-0.65 * * *$ & $-0.45 * * *$ \\
\hline$r_{18}$ & $0.72 * * *$ & $0.53 * * *$ & $0.45 * * *$ & $0.34 * *$ \\
\hline$r_{18,2}$ & -0.02 & 0.14 & $0.40 * * *$ & $0.37 * *$ \\
\hline$r_{15,23}$ & 0.13 & $0.34^{*}$ & 0.07 & $0.28^{*}$ \\
\hline$r_{15,234}$ & -0.18 & $0.35^{*}$ & $0.22 *$ & $0.34^{*}$ \\
\hline
\end{tabular}
coefficients or $\beta$-coefficients:

$\begin{array}{lcccc} & \text { Al } & \text { org. C } & \text { pH } & \text { Fe } \\ \text { Clay soils } & 0.66 & 0.25 & 0.30 & 0.13 \\ \text { Silt and loam soils } & 0.23 & 0.59 & 0.31 & 0.11 \\ \text { Sandy soils } & 0.19 & 0.82 & 0.27 & 0.11 \\ \text { Organic soils } & 0.12 & 0.53 & 0.30 & 0.20\end{array}$

The rank of these four variables in order of importance is the same as it is according to the coefficients of partial correlation (Table 3).

Table 3. Total and partial correlation coefficients for the relation between titratable nonexchangeable acidity (1), oxalate soluble $\mathrm{Al}$ (2), organic C (3), pH (4), and oxalate soluble Fe (5) 


\section{Discussion}

The terms used for the characterization of different parts of soil acidity vary, as do also methods of their determination. Unbuffered $\mathrm{N} \mathrm{KCl}$ is nowadays again employed for the replacement of acid cations at "the soil $\mathrm{pH}$ ", and titratable acidity is often measured with $\mathrm{BaCl}_{2}$-triethanolamine at $\mathrm{pH}$ 8.2. In this work, $\mathrm{KCl}$ was used instead of $\mathrm{BaCl}_{2}$ even in the latter case, and it is likely that the results differ to some extent from those which could have been obtained with $\mathrm{BaCl}_{2}$.

Apparently, in most soils with a low anion exchange capacity, titratable nonexchangeable acidity is more or less equivalent to "the $\mathrm{pH}$-dependent cation exchange capacity» or the difference in the CEC e.g. at $\mathrm{pH} 8.2$ and at the $\mathrm{pH}$ of soil. Usually, it is mainly attributed to weak acidic groups of organic matter, but also to some extent to the proton dissociation of exposed OH-groups of clay particles. Yet, according to BoLt (1961) the exchange capacity of montmorillonite and illites remains practically constant in the $\mathrm{pH}$ range from 4 to 8, and deVilliers and JAckson (1967) proved that no pH-induced CEC was present in kaolin and vermiculite. These authors claim that the "latent acidity" of clay minerals free of sesquioxide coatings is provided only by the deprotonation of $\mathrm{AlOH}_{2}$ groups at edges of fixed interlayer hydroxy- $\mathrm{Al}$ units.

This kind of polymeric hydroxy-Al interlayers are typical of chemical weathering of acid soils (JACKsON 1963), and apparently, these intergrade minerals are not lacking in Finnish clays (Soveri 1956). Yet, it is likely that positively charged Al hydroxides as surface coatings contribute more to the $\mathrm{pH}$-dependent $\mathrm{CEC}$ and titratable nonexchangeable acidity in our soils than as blocks of the interlayer spaces of 2:1 clay minerals.

Tamm's acid ammonium oxalate is supposed to extract from soils free $\mathrm{Al}$ oxides and hydrous oxides. It is doubtful, whether the hydroxy $\mathrm{Al}$ polymers in the interlayer spaces of layer silicates will be dissolved to any significant degree (cf. Dixon and JAckson 1962, Wiklander and Aleksadrovic 1969). It is also uncertain, whether Al fixed by soil organic matter is completely released by this extract. On the other hand, it probably dissolves $\mathrm{Al}$ compounds which are not blocking exchange sites or acting as proton donors. Although the amount of $\mathrm{Al}$ in Tamm's acid oxalate extract would not be equivalent to these forms of $\mathrm{Al}$, there apparently exists a relatively close correlation between them in the clay soils. In the other soils this correlation may be poorer, or then in these soils $\mathrm{Al}$ actually is less closely connected with titratable nonexchangeable acidity.

In the samples of the clay soil group the clay content ranges from 30 to 95 per cent, but no correlation was found between it and titratable nonexchangeable acidity. On the other hand, the latter was surprisingly closely correlated with the content of oxalate soluble $\mathrm{Al}$, even more closely than with the content of organic C. The partial correlation coefficient for the relation of titratable nonexchangeable acidity and the content of organic $\mathrm{C}$, when the effect of oxalate soluble $\mathrm{Al}$ was eliminated, was markedly lower than the corresponding total correlation coefficient. This may be taken to indicate that a marked part of the total correlation between titratable nonexchangeable acidity and organic $\mathrm{C}$ might be due to $\mathrm{Al}$ fixed by organic matter.

In all mineral soil groups, but particularly in the clay soils, oxalate soluble Fe appeared to be less important than $\mathrm{Al}$ in relation to titratable nonexchangeable acidity. This could be caused by the possibility that acid oxalate removed in dark only the most reactive part of Fe hydrous oxides (cf. Schwertmann 1964), and this part is not closely correlated with 
the amount of Fe which would contribute to soil acidity. On the other hand, the present results are in accordance with the findings of Coleman and Thomas (1964) that Al hydroxide seems to cover negative sites of clays more effectively than Fe hydroxide.

In the organic soils the correlation of both oxalate soluble $\mathrm{Al}$ and $\mathrm{Fe}$ with titratable nonexchangeable acidity was insignificant or very low, and Fe seemed to be more important than $\mathrm{Al}$. Because this group was small and heterogeneous, it is obvious that a larger material and more thorough studies are needed before any conclusions may be drawn on the mutual contribution of $\mathrm{Al}$ and $\mathrm{Fe}$ to titratable nonexchangeable acidity in various kind of organic soils.

It is likely that, at least, a small part of the titratable nonexchangeable acidity even in Finnish soils originates from anion exchange. Sulphate or phosphate ions or other acid radicals sorbed by positively charged $\mathrm{Al}$ and $\mathrm{Fe}$ hydroxides may be replaced by $\mathrm{OH}^{-}$ions. On the basis of the present data, it is not possible to estimate the contribution of this exchange to the consumption of base when these soils were titrated. The relatively high phosphate sorption capacity of our soils (KaIla 1959, 1963) points to the possibility that this will not be quite insignificant.

Though further studies are necessary to elucidate more thoroughly the role of $\mathrm{Al}$ in acidity of Finnish soils, it is apparent that $\mathrm{Al}$ not only as monomeric trivalent ion, but probably to a much larger extent as polymeric hydroxy $\mathrm{Al}$, increases the amounts of lime needed to amend our soils.

\section{REFERENCES}

Barshad, I. 1960. The effect of the total chemical compositon and crystal structure of soil minerals on the nature of the exhangeable cations in acidified clays and in naturally occurring acid soils. Int. Congr. Soil Sci., Trans. 7th (Madison, Wis.) 2: 435- 444.

Bolt, G. H. 1960. Cations in relation to clay surfaces. Ibid. 2: $231-237$.

Chernov, V. A. 1964. The nature of soil acidity. Soil Sci. Soc. Amer., Madison, Wis., 178 p.

Clark, J. S. 1964a. Some cation-exchange properties of soils containing free oxides. Canad. J. Soil Sci. 44: $203-211$.

Clark, J. S. 1964b. Aluminum and iron fixation in relation to exchangeable hydrogen in soils. Soil Sci. 98: $302-306$.

Coleman, N. T. \& Thomas, G. W. 1964. Buffer curves of acid clays as affected by the presence of ferric iron and aluminum. Soil Sci. Soc. Amer. Proc. 28: 187-190.

Coleman, N. T., Thomas, G. W., le Roux F. M. \& Bredell, G. 1964. Salt-exchange and titratable acidity in bentonite-sesquioxide mixtures. Ibid. 28: 35-37.

Coleman, N. T., Weed, S. B. \& McCracken, R. J. 1959. Cation-exchange capacities and exchangeable cations of Piedmont soils of North Carolina. Ibid. 23: 146-149.

Drxon, J. B. \& Jackson, M. L. 1962. Properties of intergradient chlorite-expansible layer silicates of soils. Ibid. 26: $358-362$.

Jackson, M. L. 1963. Aluminum bonding in soils: a unifying principle in soil science. Ibid. 27: 1-10.

KaIlA, A. 1959. Retention of phosphorus by peat samples. J. Sci. Agr. Soc. Finland 31: 215-225.

KaIlA, A. 1963. Dependence of the phosphate sorption capacity on the aluminium and iron in Finnish soils. Ibid. 33: 165-177.

KerÄnen, T. 1946. Kaliumista Suomen maalajeissa. Summary: On potassium in Finnish soils. Acta Agr. Fenn. 63.

McLean, E. O. \& Owen, E. J. 1969. Effects of pH on the contribution of organic matter and clay to soil cation exchange capacities. Soil Sci. Soc. Amer. Proc. 33: 855-858.

Pionke, H. B. \& Corey, R. B. 1967. Relation between acidic aluminum and soil pH, clay and organic matter. Ibid. 31: $749-752$. 
Rich, C. I. \& Obenshain, S. S. 1955. Chemical and clay mineral properties of a Red-Yellow Podzolic soil derived from mica schist. Ibid. 19: 334-339.

SChnitzer, M. 1965. Contribution of organic matter to the cation exchange capacity of soils. Nature (London) 207: 667-668.

Schnitzer, M. \& Skinner, S. I. M. 1963. Organo-metallic interactions in soils I. Soil Sci. 96: 86-93.

Schwertmann, U. 1961. Über das lösliche und austauschbare Aluminium im Boden und seine Wirkung auf die Pflanze. Landw. Forsch. 14: 53-59.

Schwertmann, U. 1964. Differenzierung der Eisenoxide des Bodens durch Extraktion mit Ammoniumoxalat-Lösung. Zeitschr. Pflanzenern. Düng. Bodenk. 105: 194-202.

Schwertmann, U. \& Jackson, M. L. 1964. Influence of hydroxy aluminum ions on pH titration curves of hydronium-aluminum clays. Soil Sci. Soc. Amer. Proc. 28: 179-183.

Soveri, U. 1956. The mineralogical composition of argillaceous sediments of Finland. Ann. Acad. Sci. Fennicae Ser. A. III 48.

Wiklander, L. \& Aleksadrovic, D. 1969. Mineral analysis of Swedish soils I. Ann. Agric. Coll. Sweden 35: 895-919.

deVilliers, J. M. \& Jackson, M. L. 1967. Cation exchange capacity variations with pH in soil clays. Soil Sci. Soc. Amer. Proc. 31: 473-476.

YuAn, T. L. 1959. Determination of exchangeable hydrogen in soils by a titration method. Soil. Sci. 88: $164-167$.

\title{
SELOSTUS
}

\section{ALUMINIUMIN OSUUS MAITTEMME HAPPAMUUTEEN}

Armi KaIla

\author{
Yliopiston maanviljelyskemian laitos, Viikki
}

Tutkimuksessa on yritetty selvittää tilastollisin keinoin aluminiumin osuutta maittemme vaihtuvasta happamuudesta sekä vaihtumattoman titrattavissa olevan happamuuden riippuvuutta aluminiumista, jonka indikaattorina on ollut happamaan ammoniumoksalaattiin liukenevan $\mathrm{Al}: n$ kokonaismäärä. Koeaineistona oli 298 erilaista maanäytettä.

Puskuroimaton $1 \mathrm{n} \mathrm{KCl}$ uutti aluminiumia vain maanäytteistä, joiden $\mathrm{pH}\left(0.01 \mathrm{M} \mathrm{CaCl}_{2}\right)$ oli alle 5.3 . Näissä näytteissä $\mathrm{Al}$ edusti keskimäärin kolmannesta kivennäismaitten ja $16 \%$ orgaanisten maitten vaihtuvasta happamuudesta. Al määrä oli yleensä sitä suurempi, mitä matalampi maan $\mathrm{pH}$ oli, mutta vuorosuhde oli kiinteä vain savimaitten ryhmässä.

Vaihtumaton titrattavissa oleva happamuus eli "pH:sta riippuva happamuus» määritettiin $\mathrm{pH}$ 8.2:ssa neutraloituvan happamuuden ja vastaavan vaihtuvan happamuuden erotuksena. Sen ja saveksen pitoisuuden välillä ei voitu havaita vuorosuhdetta savimaitten tai hiue- ja hiesumaitten ryhmissä. Sen sijaan todettiin, että oksalaattiin liukeneva $\mathrm{Al}$ selitti yksin $78.3 \%$ sen vaihtelusta savimaissa (100 näytettä), $59.8 \%$ hiesu- ja hiuemaissa (42 näytettä), $6.5 \%$ hieta- ja hiekkamaissa (99 näytettä) ja $0.6 \%$ orgaanisissa maissa (57 näytettä). Orgaanisen C:n pitoisuuden huomioonottaminen lisäsi selittävyysasteen savimaissa $82.1 \%$ :ksi, hiesu- ja hiuemaissa $84.1 \%$ :ksi, hieta- ja hiekkamaissa $83.1 \%$ :ksi ja orgaanisissa maissa $63.7 \%$ :ksi. Maan pH:n huomioonottaminen lisäsi selittävyysastetta jonkin verran kaikissa ryhmissä, mutta oksalaattiin liukenevan raudan vain orgaanisten maitten ryhmässä.

Sekä osittaiskorrelaatiokertoimien että $\beta$-koeffikienttien perusteella titrattavissa oleva vaihtumaton happamuus riippui savimaissa eniten oksalaattiin uuttuvasta Al:sta, muissa maissa orgaanisen C:n pitoisuudesta. Näissä ryhmissä $\mathrm{Al}$ näytti olevan vähemmän tärkeä kuin $\mathrm{pH}$, orgaanisten maitten ryhmässä jopa oksalaattiin uuttuva rauta vaikutti tärkeämmältä. 